\title{
Apresentação do dossiê: Sob a pena de Eça: leituras ecianas no século XXI
}

\author{
Alana de Oliveira Freitas El Fahl* \\ Universidade Estadual de Feira de Santana \\ Feira de Santana, Bahia, Brasil \\ Carlos Reis ${ }^{* *}$ \\ Universidade de Coimbra \\ Coimbra, Portugal
}

O presente dossiê, subordinado ao título genérico Sob a pena de Eça: leituras ecianas no século XXI, inclui seis artigos de temática variada e visando diferentes tempos e géneros literários da produção queirosiana. Tal pluralidade torna evidente o que é sabido, mas deve ser repetido: estamos perante a obra de um dos mais fecundos, complexos e diversificados escritores da literatura de língua portuguesa; ao mesmo tempo, as "leituras ecianas no séculos XXI" dão testemunho da constante renovação dos estudos queirosianos, protagonizada por ensaístas que confirmam a relevância que, desde sempre, aqueles estudos conheceram no Brasil. Por outras palavras: a geração atual de estudiosos de Eça dá sequência aos trabalhos de estudiosos como, entre outros, Álvaro Lins, Djacir Menezes, Clóvis Ramalhete, Arnaldo Faro, Luís Vianna Filho, Dário Castro Alves, Paulo Cavalcanti, Beatriz Berrini e Elza Miné.

Situada na linha da frente do Realismo português, a importante produção literária de Eça de Queirós oferece ainda orientação à cultura e à literatura em língua portuguesa neste século XXI. A sua contribuição para a nossa cultura representa um ponto pacífico entre os críticos, já que é notória a ativa itervenção de Eça na construção das bases ideológicas e estéticas da segunda metade do século XIX, com importantes prolongamentos no século XX e até aos nossos dias. Não por acaso, a referência à atualidade do genial autor d'Os Maias tornou-se quase obrigatória, quando pensamos na sua obra e a relemos à luz das nossas perocupações de agora.

Essa vasta obra compreende romances (que são, evidentemente, o fulcro do legado queirosiano), contos, correspondências, textos jornalísticos e ensaios, dentre outros gêneros que continuam sendo fonte de interesse para leitores e para estudiosos, na contemporaneidade. Quando foi lançado, o objetivo do dossiê Sob a pena de Eça: leituras ecianas no século XXI era estimular estudos que abordassem a obra do escritor português, através de diversas perspectivas de análise; o conjunto de ensaios a seguir publicados mostra, de forma bem expressiva, que aquele objetivo foi cumprido.

\footnotetext{
* Professora Titular de Literatura Portuguesa do Departamento de Letras e Artes, da Universidade Estadual de Feira de Santana, doutora em Letras e Linguística pela UFBA. E-mail: alana_freitas@yahoo.com.br.

** Professor catedrático e leciona Literatura Portuguesa, Teoria da Literatura e Estudos Queirosianos, da Universidade de Coimbra. É coordenador do Centro de Literatura Portuguesa. E-mail: c.a.reis@mail.telepac.pt.
} 
Numa referência necessariamente breve ao conteúdo do presente dossiê, importa notar que dois dos textos que o integram incidem sobre santos queirosianos: frei Genebro, protagonista do conto epónimo, publicado pela primeira vez em 1894, na Gaz̧eta de Notícias do Rio de Janeiro, e incluído na edição crítica dos Contos I, por Marie-Hélène Piwnik; São Frei Gil, postumamente inserido por Luís de Magalhães, no volume Últimas Páginas (1912).

A Frei Genebro consagra Ana Márcia Alves Sequeira uma análise que, entre outros aspetos, valoriza uma escrita do implícito e do pormenor, no quadro de uma arquitetura narrativa própria, conjugada com diferentes recursos estilísticos e com específicas estratégias discursivas. Antônio Augusto Nery (autor de vários estudos sobre a religiosidade em Eça) e Eduardo Soczek Mendes debruçam-se sobre São Frei Gil, talvez a mais enigmática das três lendas hagiológicas queirosianas, para mostrar que o escritor, em fim de vida literária, retorna ao imaginário da tradição e supera a escrita irônica dos anos do Realismo.

Em As velhas novas casas de Usher, Juliana Rodrigues Salles e Mirella Márcia Longo Vieira Lima realçam pontos comuns de um conto de Edgar Allan Poe, AQueda da Casa de Usher (1839), com Os Maias e com A Crônica da Casa Assassinada, de Lúcio Cardoso, pelo viés da literatura gótica e da descrição de atmosferas de decadência e finitude. Por sua vez, Izabel Margato, no ensaio com que contibui para este dossiê, procede a uma leitura do discurso de António Ferro intitulado "O Centenário de Eça de Queirós”, como testemunho axial para se perceber a componente histórico-política que foi incutida, em 1945, às comemorações do centenário de Eça.

Marcio Jean Fialho de Sousa parte da lição de Michel Foucault para analisar os processos de anacorese e da chamada escrita de si em relatos de Eça em cujo registo semionarrativo tais processos são visíveis; no caso, o foco da análise adotado incide em especial sobre $A$ Relíquia e sobre o seu protagonista. Por fim, Cristiane Navarrete Tolomei inscreve, no título que adota ( $O$ último Eça de Queirós na imprensa paulistana: nacionalismo e tradição), aquela expressão com que temos designado a produção queirosiana dos derradeiros anos de vida literária, eventualmente identificada com problemas, com valores e com atitudes estéticas do fim do século; está em equação a recepção do último Eça em três jornais de São Paulo, o Correio Paulistano, O Estado de S. Paulo e a Revista do Brasil, no período que vai da morte do escritor às comemorações do centenário do seu nascimento.

Tudo resumido, é nossa convicção de que os contributos que aqui ficam cumprem, de forma inequívoca, uma dupla função: por um lado, eles atestam a diversidade de aspetos da obra queirosiana que são merecedores de leitura crítica, mesmo quando não estão em causa as obras maiores do grande escritor; por outro lado, fica evidenciada a vitalidade dos estudos queirosianos no Brasil, para mais configurando um mapa em que estão representadas diversas áreas da geografia académica brasileira que cruzam o oceano e se encontram aquém e além-mar (Feira de Santana e Coimbra) e reforçam as forças culturais e estéticas que habitam sob a pena de Eça. 